\title{
Human Resource Factors and Organisational Commitment at the College of Distance Education, University of Cape Coast
}

\author{
Moses Segbenya ${ }^{1}$, Ebenezer $\operatorname{Aggrey}^{2}$ \& Fred Peniana $^{3}$ \\ ${ }^{l}$ Department of Business Studies, College of Distance Education, University of \\ Cape Coast \\ ${ }^{2}$ School of Economics, University of Cape Coast \\ ${ }^{3}$ School of Physical Sciences, University of Cape Coast \\ Email: msebenya@ucc.edu.gh ${ }^{1}$
}

\section{Abstract}

The study examined human resource factors and organisational commitment at the College of Distance Education, University of Cape Coast, Ghana. The research approach was quantitative, specifically using a descriptive study design. Out of 242 staff of the College, a sample of 148 respondents (comprising 18 senior members, 80 senior staff and 50 junior staff) were drawn across the three spectrums of staff using Krejcie and Morgan (1970) sample determination formula. The main instrument for data collection was a selfadministered questionnaire. Data of the study was analysed with means, standard deviations, independent ttest, two-way analysis of variance and Spearman rank order correlations matrix. The study found that commitment level among staff at the college (CoDE) was high and affective commitment was perceived higher than normative and continuance dimensions of organisational commitment. Work relations were perceived as higher than extrinsic rewards and training and development. It was also found that training and orientation significantly relate to organisational commitment. Sex and age of respondents did not affect organisational commitment and other variables of the study. It was recommended that management of the college should continue to pay more attention to work relations at the college by engaging staff of the 
college in inter-unit or interdepartmental assignments to enable staff to build more work relations and used both on-the-job and off-the-job training techniques to maintain or increase commitment level among staff of the college.

Keywords: Extrinsic rewards, work relations, training and orientation, commitment 


\section{Introduction}

The goals of higher education are to provide in-depth knowledge, seek academic development, educate students, and to coordinate developmental demands (Betz, 2005). In the attempt to expand the educational frontiers and extend these educational goals to cover a broad spectrum of qualified applicants, some tertiary educational institutions have introduced distance education in addition to the regular mainstream academic programmes (Moore \& Kearsely, 2005). However, the attainment of distance educational goals largely depends on the availability of committed and competent employees. This suggests that the human resources of every distance educational institution remain the most important resource for the survival and growth of that institution. Without it, all other resources would lie idle and unproductive (Jackson \& Mathis, 2010). Thus, the survival of a distance education institution depends on employees' commitment. Employees' commitment is underpinned by Becker's (1960) side-bet theory of commitment. Becker's side-bet theory postulates that "contract" of economic exchange defines the kind of relationship between employee's commitment towards an organisation (Irefin \& Ali 2014). Thus, an employee could hardly claim the investments of "side-bet" if he/she decides to quit the organization. Becker (1960) therefore argued that since over a period certain costs accrue; it makes it more difficult for an employee to disengage from maintaining membership in the organization. Employee social and economic investment over time in an organisation come in the form of income, status, seniority, friendship and institutional memory or technical knowledge, cannot easily be recouped or claimed if one loses membership (Kessler, 2013). Kessler described this kind of commitment in the 1960s as the calculative approach to defining and measuring commitment.

Another approach to measuring and describing employees' commitment emerged from the 1970s to mid-1980s called organisational behaviour or psychology approach of commitment by Porter, Steers, Mowday, and Boulian (1974). Unlike, Becker's (1960) side-step theory of commitment which argued from the perspective of economic and social accumulation over time, the second 
approach (the attitudinal approach) described commitment as affective or attitudinal. Thus, Porter, Steers, Mowday, and Boulian (1974) were of the view that employees get committed to their organisation because they identify with the organisational values and goals. The emphasis during the attitudinal approach was based on the desire to maintain membership in the organization, belief in and acceptance of the values and goals of the organisation and lastly willingness to exert effort on behalf of the organization.

Meyer and Allen (1984) introduced the multidimensional approach to describe and measure employees' commitment in 1984. The multidimensional approach was initially based on two main pillars such as affective commitment (like the Becker's side-bet theory) and continuance commitment. Continuance commitment was explained as the degree to which employees feels committed to their organisation by the virtue of their perception of the cost associated with leaving. Meyer and Allen (1984) however, later added a third dimension to the multidimensional approach, which was normative commitment. Normative commitment describes an employee's feeling of obligation to remain with the organization. Even though the debate on how to describe and measure employees' commitment has not ceased, it is now generally accepted to describe and measure employees' commitment from the three perspectives such as affective commitment, normative commitment and continuance commitment. Details of these dimensions are provided under theoretical perspective under a literature review of this study.

The University of Cape Coast established the College of Distance Education (CoDE) (Hitherto Centre for Continuing Education) in 1997 with the vision of becoming the leading provider of quality distance and continuing education in Ghana and beyond. The College's mission is to remain as the excellent institution for planning and delivery of innovative, demanddriven, customer-oriented and costeffective continuing and distance education programmes, aimed at assisting individuals in overcoming geographical, economic, social and cultural barriers to learning, and for national development. In order to achieve its mission, the college has 
divided its activities into two main categories.

The first component of the college's activities focuses on activities performed during weekdays usually from Mondays to Thursdays. This category of activities serves as the preparatory period of the college's activities, which are largely administrative in nature. It also includes resolving students' challenges, printing of questions, getting study materials ready for students as well as synchronizing information (announcement) to be sent to students. The second category of activities of the college is basically teaching and monitoring of academic activities in over 83 study centres of the college across the length and breadth of Ghana during weekends. Invigilation of continuous assessment and end of semester examination as well as receiving students' complaints from study centre coordinators are also part of the weekend's activities.

The college is headed by a provost and administrative staff (college registrar and college finance officer), aided by heads of departments, unit coordinators and regional coordinators. Most of the staff at the College were transferred from the mainstream of the University and others were brought in as part of the Colleges' effort of capacity building. The staff of the College comprised senior members, senior staff and junior staff. In terms of reward system, staff are paid salary for their weekdays' activities and allowances for their weekends' activities.

The nature of activities at the college (on weekdays and weekends) requires that staff of the college are committed. This is because committed employees are easy to be retained even though they may not necessarily be satisfied employees as argued from the perspective of normative and affective approaches of commitment theory (Kessler, 2013). Employees of the college also need to be committed to enable the college to deliver on its mandates since organisational performance largely depends on committed staff (Coetzee, Schreuder \& Tladinyane, 2014).

Thus, the college's ability to achieve its aim of becoming a leading provider of quality distance education in Ghana and Africa hinges on committed staff. The competition faced by the college from other providers of distance education in Ghana (from 
universities and colleges of education) could be largely dealt with when committed staff are on board to deliver on the College's mandate. Meanwhile, employees' performance is not just an antecedent of organisational commitment but also depends on other human resource functions or practices. Key among these human resource practices are training and orientation that staff joining the college receives to enhance their skills and competencies for performance.

The staff of the college work in relation with other staff members in their departments and units. Thus, individual performance could also be highly influenced by the kind of human relationships that exists among staff at the college. From the calculative approach of the theory of commitment, reward as an economic benefit and a human resource function could also be a determinant of employees' commitment. However, earlier studies on the college by Segbenya, Peniana and Aggrey (2018) looked at other human resource practices such as work-life balance and employee job satisfaction among others.

This study thus focused on other understudied variables such as work relations, rewards system and training and orientation, and how these variables relate to employee commitment. Thus, the need to determine whether staff of the college are committed due to positive feelings of attachment to the college (from the perspective of affective commitment), cost associated with leaving (from the continuance commitment perspective) or feeling of obligation to stay in the organisation (from normative commitment dimension) has become very relevant and urgent. The increasing demand and reliance on the activities of CoDE make it imperative to undertake this study. Thus, this study sought to fill this research gap.

The purpose of the study was to examine predetermined factors that influence employee commitment at CoDE. The specific research questions and associated hypotheses of the study were:

1. What is the level of employee commitment among a staff of CoDE, UCC?

2. How do employees perceive work relations, training and orientation and extrinsic reward at CoDE, UCC?

Hypothesis One 
H0: There is a statistically positive significant relationship between organisational commitment and variables of the study such as work relations, training and orientation, and extrinsic rewards.

Hypothesis Two

H0: There is a statistically significant difference between the sex of respondents and the variables of the study such as work relations, training and orientation, extrinsic reward and organisational commitment.

Hypothesis Three

H0: There is a statistically positive and significant difference between the type of employment and variables of the study such as work relations, training and orientation, extrinsic reward and organisational commitment.

Hypothesis Four

H0: There is a statistically significant difference between the types of organisational commitment and tenure.

\section{Literature Review}

The first part of this section of the paper focuses on the theoretical perspective of organisational commitment theory. The three historical angles of organisational commitment theory such as calculative, attitudinal and multidimensional approaches have already been catered for in the background. Thus, the discussion under this section focuses on the three major perspectives on organisational commitment theory such as affective, continuance and normative commitment (Irefin \& Ali, 2014).

Affective dimension of the commitment theory describes employee's emotional attachment to, identification with, and involvement in the organisation. A strong effective commitment to an organisation is characterized by employees' decision to maintain their continuous membership or employment with the organisation (Meyer \& Allen, 1987). Four antecedents of affective commitment include personal characteristics, structural/organisational characteristics, job-related characteristics, and lastly, demographic characteristics such as 
work experiences, age, tenure, gender and education and job status.

The second dimension of commitment theory which is continuance commitment relates awareness of the costs associated with leaving an organisation. The potential costs of leaving an organisation include giving up seniority-based privileges, losing attractive benefits, the threat of wasting the time and effort spent acquiring nontransferable skills or having to 'uproot' family and disrupt personal relationships. Additionally, continuance commitment also develops as a function of a lack of alternative employment opportunities. Thus, workers whose primary link to the organisation is based on continuance commitment remain because they need to.

The feeling of obligation to continue employment also constitute a normative commitment. Employees with a high level of normative commitment are characterized by the feeling of 'I ought to remain with this organisation'. Normative commitment is influenced by an organisation's provision of "rewards in advance" to a work like the payment of school fees or incurring significant costs in providing employment in the form of headhunting fees or the costs associated with a job. Other factors associated with normative commitment include cultural orientation (prior to entry into the organization), and organisational orientation (following entry). Recognition of these investments causes employees to feel an obligation to reciprocate by committing themselves to the organisation until the debt has been repaid.

The second section of the literature review of this paper focuses on conceptual discussions on HRM factors of the study and employee commitment. The HRM factors of this study are work relations, training and orientations, and reward systems. Other HRM factors such as job satisfaction, work and life balance among others are not the focus of this study because they have been studied by Segbenya, Aggrey and Peniana (2018) on the same study institution. Also, other HRM practices or factors such as recruitment and selection, performance appraisal and promotions were also excluded from this study because the college has little or no influence over these factors at the college level. 
Work Relations and Commitment

Generally, work relations in the workplace is a type of interpersonal relationship based on two concepts-the leader-member relationship and coworkers' interactions (Paşaoğlu \& Becker 2015). This description did not consider the quality dimension of work relation. For this reason, Jørgensen, and Becker (2015) added that work relations can be described as the quality of the interpersonal relationship that exists between employees and co-workers (the horizontal pair) and their supervisors (the vertical pair).

A more specific and elaborated description indicating the antecedents of work relation was however given by Sawithri, Nishanthi and Amarasinghe (2017) that workplace employee collaboration encompasses office politicking, level of an interpersonal relationship among workers, backstabbing, empire building, rumour mongering, alienation, trust or mistrust and sabotage. Work relation is relevant for achieving social reciprocity of resources, support and participation in decisionmaking, trust and respect, quality of teamwork and ultimately, organisational

commitment

(Funminiyi, 2018).

Training and Orientation, and Commitment

Training is a planned process to modify attitudes, knowledge or skill behaviour through learning experience to achieve effective performance in an activity or range of activities (Wan, 2007). This means that training basically leads to sharpening the skills and the competencies of employees either "on or of" the job for better performance in their present or future job roles.

Orientation, on the other hand, is a form of training given to new employees to familiarize themselves with the new workplace and the necessary facilities, activities of the organisation, work colleagues among others (Jafari, Afshin, Jafari, \& Barzegar, 2015). Thus, organisations that are committed to employee training benefit from the rewards of increased skill sets, motivation, higher productivity and knowledge transfer of their employee. Training enhances employees' skills, reduces role conflict and prepares them for future advancements, reduces employee 
turnover, hence increases their level of commitment (Funminiyi, 2018).

\section{Extrinsic Rewards and Commitment}

Extrinsic rewards are usually financial and tangible rewards given to employees by managers, such as pay raises, bonuses, and direct financial benefits in return for services rendered (Armstrong, 2007). Extrinsic reward continues to play a dominant role in the lives of workers because it is a key determinant for workers' decision to accept and stay on a job (Shaw, 2015). Extrinsic rewards remain one of the most significant motivational strategies for workers (Armstrong \& Murlis, 2007). Comparing the effect of pay growth effects on turnover intentions among staff categories, Sthapit (2014) argues that pay growth or extrinsic reward greatly influenced talented employees than other categories of staff.

The overall benefit of extrinsic reward was also highlighted by Mahesar (2015) that organizations that provide its workers with a good extrinsic reward or compensation get in return committed employees who are willing to keep their employment arrangement with their employer for a long term. Arguing from the institutional image perspective, Paşaoğlu (2015) concluded that extrinsic reward is not only necessary for employees but also raises the goodwill of employers in the job market, as a fair and rational organization.

The last section of the literature review of this study looks at the empirical studies on the variables of the study such as work relations, training and orientation, and extrinsic rewards. Coffie, Agyenim -Boateng and Coffie, (2018) found that the quality of information shared among coworkers and supervisors positively correlate with the three dimensions of commitment such as continuance, affective and normative commitment. Funminiyi (2018) rather found that trust in supervisor and co-workers were significantly related to the two dimensions of commitment such as affective commitment in supervisor and explained significant variance in affective commitment in supervisor.

Brunetto, Xerri, Shriberg, Rod, Newman, Dienger (2013) found a very significant relationship between workplace relations and organisational commitment among nurses in the US and Australia. Telman and Unsal (2004) also 
concluded that relationship with supervisors and colleagues at the workplace was an external factor that affects employee commitment. Thus, work relations affect employees' commitment, however, at the CoDE, UCC, it is not clear how this factor affects the commitment level of staff.

A study carried out by Coffie, Agyenim -Boateng and Coffie, (2018) found that training only relates to two dimensions of commitment such as affective and normative commitment. Peretomode and Bello (2018) also found that training affected teachers' commitment along the three dimensions of commitment. It can, therefore, be concluded that training and orientation affect employees' commitment, however, it is not clear how training and orientation affect the dimensions of commitment at CoDE/UCC.

Gellatly, Hunter, Currie and Irving (2009) found a significant relationship between firms' compensation packages and employees affective and continuance commitment towards their organization. Shaw and Gupta cited in Mahesar (2015) investigated the relationships between pay dispersal and the quits patterns of good, average and poor performers among
226 US truck drivers. The study found that under high pay practices, pay dispersal was negatively associated with good employees' quit rates when performance-based pay increases were underlined and positively associated when they were not. Also, under high pay practices, pay dispersal was negatively connected to average performer quits when seniority-based pay increases were underlined, but this relationship was diminished when they were not. However, pay dispersal was not constantly related to quilt patterns, when pay was small.

\section{Methodology}

This study adopted the quantitative research approach, specifically a descriptive study design. The reason that necessitated the use of this design was that the study sought to describe (Amedahe \& Gyimah, 2016) how human resource factors relateto employee commitment at CoDE. The Total population of the study was 242 employees of CoDE comprising 30 senior members, 130 senior staff, and 82 junior staff. Samples of 148 respondents were drawn across the three spectra of staff. Krejcie \& Morgan (1970) sample determination formula was used to sample 148 
respondents out of the 242 population of the study. The formula used is as follow:

$$
\mathrm{S}=\mathrm{X}^{2} \mathrm{NP}(1-\mathrm{P}) / \mathrm{d}^{2}(\mathrm{~N}-1)+
$$

$\mathrm{X}^{2} \mathrm{P}(1-\mathrm{P})$

Where $\mathrm{s}=$ required sample size; $\mathrm{X}^{2}=$ the table value of chi-square for 1 degree of freedom at the desired confidence level (3.841); $\mathrm{N}=$ the population size, $\mathrm{P}=$ the population proportion (assumed to be .50 since this would provide the maximum sample size) and $d=$ the degree of accuracy expressed as a proportion (.05). Thus $\mathrm{S}=3.841 * 242 * 0.50(1-$ $0.50) / .05^{2} \quad(242-1)+3.841 * 0.50(1-$ $0.50)=148$ sample for the study.

Firstly, a list of staff was obtained, and each member of the population was assigned a unique number. In the next step, these numbers were written on separate cards which were physically similar in shape, size, color etc. Then they were placed in a box and thoroughly mixed and the slips were taken out randomly without looking at them until number/sample required was attained. Thus, the lottery method of the simple random was used for the study. The 148 sample was further proportionately distributed across the three staff categories and specific sample for each category can be seen from Table 1.

Table 1: Distribution of Sample Across Spectrum of Staff of the College

\begin{tabular}{lccc}
\hline Category & Population & $\%$ & $\begin{array}{l}\text { Proportionate Sample } \\
\text { Drawn }\end{array}$ \\
\hline Senior members & 30 & 12 & 18 \\
Senior Staff & 130 & 54 & 80 \\
Junior Staff & 82 & 34 & 50 \\
Total & 242 & 100 & 148 \\
\hline
\end{tabular}

Source: CoDE, 2016 
Data collection instrument was self-administered questionnaire. The questionnaire captured both opened and close-ended items. The opened ended items were coded and assigned values due to the quantitative approach or design adopted. Training and orientation as a variable in this study was measured by four items adapted from Delery and Doty's (1996) study and four other items personally developed. Furthermore, four items about extrinsic reward/pay was adapted from the scale developed by Price and Mueller (1986) with two items personally developed. OC was measured with Porter et al.'s (1974) fifteen-item scale (which was modified into nine items) which considered all dimensions of the commitment- affective, continuance and normative commitment.
The last variable of the study which was work relation was assessed with the six-item scale developed by Mahesa (2015). The questionnaire was divided into five sections with section one focused on demographic characteristics of respondents and the remaining four sections dealing with the four variables of the study such organisational commitment, intrinsic reward, work relations and training and orientation. The Cronbach's alpha for the variables of the study can be seen from Table 2. The data collection instrument (questionnaire) had items that were measured on a scale of 1 to 4 with 1 representing strongly disagreement while 4 represented strong agreement. In all 115 completed questionnaires was received representing a response rate of 78 percent.

Table 2: Cronbach's Alpha for Variables of the Study

Dependent variable Cronbach's alpha Number of items

Organisational Commitment

.648

9

Independent variables

Intrinsic Rewards/allowance

.823

Work relations

.856

6

Training and orientation 
Source: Field survey (2017)

Data gathered through openended items were coded and analysed quantitatively with data gathered through close-ended items. Specifically, descriptive and inferential statistical tools were employed for the data analysis. Means and standard deviations were used to analysed objectives one and two. Independent t-test was used to test hypotheses two and three and spearman rank order nonparametric correlation matrix was used to test for hypothesis one. Lastly, Analysis of Variance (ANOVA) was also used to analysed hypothesis four.

\section{Results and Discussion}

Presentation in this section is based on the research questions that the study sought to answer. The first research question concerned the level of employee commitment among staff of CoDE. In order to answer this question, means and standard deviations were calculated and the results can be seen from Table 3. The scale of the items on the questionnaire were rated from one to four. Thus, adding $1+2+3+4=10 / 4=2.5$. This means that all means values from the threshold of 2.5 and above is regarded as high and vice versa. It is evident from Table 3 that only three items were rated high since their means values were above the 2.5 threshold. These items bordered on intention to continue work with the college if possible $(\mathrm{M}=2.8696 ; \mathrm{SD}=.80005)$; willingness to recommend the college as a good working place to colleagues $(\mathrm{M}=2.7478 ; \mathrm{SD}=.81481)$ and the influence of work relations on respondents' decisions to stay with the college $(M=2.6174$; $\mathrm{SD}=.8227)$.

The results suggest that commitment level among CoDE staff was found to be high. The assertion of high commitment among staff is further corroborated by the low rating of all the remaining items forming the commitment variable of the study. This is because these low items suggest that workers' were not prepared to quit the college to other institutions for a better conditions of service $(M=1.9217 ; S D=.78526)$, if offered more salary and allowances by other employers ( $M=2.1739$; $\mathrm{SD}=.91057)$ and do not feel like 
quitting the college at times $(\mathrm{M}=2.2522 ; \quad \mathrm{SD}=.98090)$. This finding agrees with that of Brunetto, Xerri, Shriberg, Rod, Newman, Dienger (2013) that committed employees are always prepared to recommend their organisation to their colleagues.

Table 3: Commitment Level Among CODE Staff

Commitment Variables

$\mathrm{N} \quad \dot{\Sigma}: \Sigma{ }_{\kappa}^{\times}$Mean Std. Dev.

I intend and wish to work with CoDE for as long as possible

$\begin{array}{lllll}115 & 1.00 & 4.00 & 2.8696 & .80046\end{array}$

I will recommend CoDE to my friends

$\begin{array}{lllll}115 & 1.00 & 4.00 & 2.7478 & .81481\end{array}$

I will not feel guilty if I leave CoDE now

$\begin{array}{lllll}115 & 1.00 & 4.00 & 2.4348 & .84946\end{array}$

I am with CCE because there are good work relationships

Staying with CoDE, right now, is a matter of necessity

$\begin{array}{lllll}115 & 1.00 & 4.00 & 2.4174 & .86838\end{array}$

I intend retiring in my present job

$\begin{array}{lllll}115 & 1.00 & 4.00 & 2.3478 & .98269\end{array}$

I sometimes feel like leaving CoDE

$\begin{array}{lllll}115 & 1.00 & 4.00 & 2.2522 & .98090\end{array}$

I will quit CoDE if offered more salary and allowance by any employer

$\begin{array}{lllll}115 & 1.00 & 4.00 & 2.1739 & .91057\end{array}$

If the conditions of service improved, I will still quit CoDE

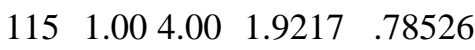

Source: Field survey, $2017 \quad$ Scale: $1.9-2.4=$ Low and 2.5 and above $=$ High

In terms of how categorisation, the results can be seen commitment level among staff of the from Table 4. Results in Table show college differ according to staff the three categorisations of staff of 
the college against the three dimensions of commitment. The results indicate that affective commitment $\quad(\mathrm{M}=\quad 2.6087$; $\mathrm{SD}=.06107)$ was perceived higher than normative $(\mathrm{M}=2.4348$, $\mathrm{SD}=.84946)$ and continuance $(\mathrm{M}=2.4174 ; \mathrm{SD}=.86838)$ dimensions of organisational commitment.

Specifically, senior members of the college perceived affective commitment higher $(\mathrm{M}=3.05 ; \mathrm{SD}=.350)$ followed by junior staff $(\mathrm{M}=2.85, \mathrm{SD}=.642)$ and senior staff $(\mathrm{M}=2.45 ; \mathrm{SD}=.643)$. This kind of commitment at the college was influenced by workers' emotional attachment to, identification with, and involvement in the activities of the college. The finding is in tandem with Irefin and Ali (2014) that strong affective commitment to an organisation is characterized with employees' decision to maintain their continuous membership or employment with the organization.

Table 4: Commitment Level According to the Three Categorisation of Staff

\begin{tabular}{llrrrr}
\hline & & N & Mean & Std. Dev. & $\begin{array}{r}\text { Std. } \\
\text { Error }\end{array}$ \\
\hline Affective Commitment & Senior Member & 11 & 3.05 & .350 & .10563 \\
& Senior Staff & 75 & 2.45 & .643 & .07424 \\
& Junior Staff & 29 & 2.85 & .642 & .11927 \\
& Total & 115 & 2.61 & .655 & .06107 \\
Continuance & Senior Member & 11 & 2.18 & 1.17 & .35209 \\
Commitment & Senior Staff & 75 & 2.37 & .835 & .09637 \\
& Junior Staff & 29 & 2.62 & .820 & .15227 \\
Normative Commitment & Sotal & 115 & 2.41 & .868 & .08098 \\
& Senior Member & 11 & 2.46 & 1.13 & .34015 \\
& Senior Staff & 75 & 2.51 & .795 & .09178 \\
& Junior Staff & 29 & 2.24 & .872 & .16200 \\
& Total & 115 & 2.44 & .849 & .07921 \\
\hline
\end{tabular}

Source: Field survey (2017) Scale: 2.0-2.4= Low; 2.5 and above= High 
Table 4 equally shows that continuance commitment among staff of the college was perceived to be high by only the junior staff $(\mathrm{M}=2.6207 ; \mathrm{SD}=.82001)$ of the college. The commitment of junior staff of the college was due to the cost of leaving the college which could be either losing attractive benefits (allowances), the threat of wasting the time and effort spent acquiring nontransferable skills or having to disrupt work relationship as found by Jorgensen and Becker (2-15). With regards to normative commitment, only senior staff of the college $(\mathrm{M}=2.5067$, $\mathrm{SD}=.79480$ ) followed by senior members $(\mathrm{M}=2.4545$, $\mathrm{SD}=1.12815)$ perceived it to be high.

The high level of normative commitment among the two categories of staff means these workers had a feeling of obligation (ought) to continue employment with the college. This could be possible due to support received by some members of staff who were sponsored or supported by the college to do their masters and $\mathrm{PhD}$ studies as part of the college's capacity building efforts. Recognition of these investments could have causes senior staff and senior members to have felt an obligation to reciprocate by committing themselves to the college and its activities. This finding agrees with that of Coffie, Agyenim -Boateng and Coffie (2018) that organisation's provision of "rewards in advance" to a worker, like the payment of school fees, could cause normative commitment where workers feel like I ought to stay with the organization).

How Employees Perceive Work Relations, Training and Orientation and Extrinsic Reward at CoDE

It has been established that some key antecedents of organisational commitment theory are work relations, extrinsic reward and training and orientation (Mahesar, 2015). It is for this reason that the study went further to examine how respondents perceived these antecedents of organisational commitment at CoDE. Results for respondents' perception on how these factors influenced commitment among the categorization of staff can be seen from Table 5 . 
Table 5: Respondents' Perception of Factors Influencing Commitment

\begin{tabular}{|c|c|c|c|c|c|}
\hline & & $\mathrm{N}$ & Mean & Std. Dev & $\begin{array}{l}\text { Std. } \\
\text { Error }\end{array}$ \\
\hline \multirow[t]{4}{*}{ Work Relations } & Senior Member & 11 & 2.1818 & .75076 & .22636 \\
\hline & Senior Staff & 75 & 2.5733 & .82484 & .09524 \\
\hline & Junior Staff & 29 & 2.8966 & .77205 & .14337 \\
\hline & Total & 115 & 2.6174 & .82273 & .07672 \\
\hline \multirow[t]{4}{*}{ Reward System } & Senior Member & 11 & 2.3333 & .69522 & .20962 \\
\hline & Senior Staff & 75 & 2.0422 & .59091 & .06823 \\
\hline & Junior Staff & 29 & 2.0920 & .59024 & .10961 \\
\hline & Total & 115 & 2.0826 & .60148 & .05609 \\
\hline \multirow{4}{*}{$\begin{array}{l}\text { Training \& } \\
\text { Orientation }\end{array}$} & Senior Member & 11 & 2.4205 & .46190 & .13927 \\
\hline & Senior Staff & 75 & 2.3733 & .44574 & .05147 \\
\hline & Junior Staff & 29 & 2.8405 & .53022 & .09846 \\
\hline & Total & 115 & 2.4957 & .50733 & .04731 \\
\hline
\end{tabular}

Source: Field survey (2017) Scale: 2.0-2.4= Low and 2.5 and above= High

Among the three factors examined (Work Relations, Training and Orientation and extrinsic reward) only work relations $(\mathrm{M}=2.6174$; $\mathrm{SD}=.82273$ ) was perceived to be very high among staff of the college. Training and orientation $(\mathrm{M}=2.4957$; $\mathrm{SD}=.50733$ ) and extrinsic reward $(\mathrm{M}=2.0826 ; \quad \mathrm{SD}=.60148) \quad$ were however, perceived to be low. Junior staff of the college perceived work relations $(\mathrm{M}=2.8966 ; \mathrm{SD}=.77205)$ and training and orientation $(\mathrm{M}=$
2.8405; $\mathrm{SD}=.53022$ ) higher than the other two categories of staff. Though extrinsic reward was generally perceived low across the three spectrums of staff, senior members however, rated it higher than junior and senior staff of the College.

The findings for work relations as the only factor rated high corroborate that the findings of Funminiyi (2018) that work relation ultimately leads to high commitment among workers. Meanwhile, the 
findings of this study about the low rating for extrinsic reward disagrees with that of Shaw et al. (2009) that extrinsic reward continues to play a dominant role in the lives of workers because it is a key

Testing of Hypotheses of the Study Hypothesis One

H0: $\quad$ There is statistically positive significant relationship between organisational commitment and variables of the study such as work relations, training and orientation, and extrinsic rewards.

Hypothesis of the study was tested with Spearman rank order nonparametric correlation matrix to establish relationship between the dependent and independent variables and the result can be seen from Table
6. The correlation matrix (Table 6) indicates that there was weak, positive and insignificant relationship between organisational commitment and work relation (rho=.116; $\operatorname{Sig}=.474 ; \mathrm{p} \geq 0.005$ ); and organisational commitment and extrinsic reward $\quad(r h o=.067$; $\mathrm{Sig}=.217 ; \mathrm{p} \geq 0.005$ ). It is clear from Table 6 that there was a positive and significant but weak correlation between training and orientation and organisational commitment $(\mathrm{r}=$ $\left..372^{* *}, \quad \mathrm{Sig}=.000 ; * * \mathrm{p}<0.05\right)$. This means that a percentage increase in training and orientation would result in a percentage increase in organisational commitment at the college. The results corroborate the findings of Peretomode and Bello (2018) that training affected teachers' commitment. 
Table 6: Spearman's rho Nonparametric Correlation Matrix

\begin{tabular}{|c|c|c|c|c|c|}
\hline & & $\begin{array}{l}\text { Extrinsic } \\
\text { Reward }\end{array}$ & $\begin{array}{c}\text { Training } \\
\& \\
\text { orientatio } \\
n\end{array}$ & $\begin{array}{c}\text { Work } \\
\text { Relations }\end{array}$ & $\begin{array}{c}\text { Organisation } \\
\text { al } \\
\text { Commitment }\end{array}$ \\
\hline \multirow{4}{*}{$\begin{array}{l}\text { Extrinsic } \\
\text { Reward }\end{array}$} & Correlation & 1.000 & $.317^{* *}$ & .086 & .116 \\
\hline & Coefficient & & & & \\
\hline & $\begin{array}{l}\text { Sig. (2- } \\
\text { Tailed) }\end{array}$ & . & .001 & .363 & .217 \\
\hline & $\mathrm{N}$ & 115 & 115 & 115 & 115 \\
\hline \multirow{3}{*}{$\begin{array}{l}\text { Training } \\
\text { and } \\
\text { orientation }\end{array}$} & $\begin{array}{l}\text { Correlation } \\
\text { Coefficient }\end{array}$ & $.317^{* *}$ & 1.000 & .169 & $.372^{* *}$ \\
\hline & $\begin{array}{l}\text { Sig. }(2- \\
\text { Tailed) }\end{array}$ & .001 & . & .071 & .000 \\
\hline & $\mathrm{N}$ & 115 & 115 & 115 & 115 \\
\hline \multirow{3}{*}{$\begin{array}{l}\text { Work } \\
\text { Relations }\end{array}$} & Correlation & .086 & .169 & 1.000 & .067 \\
\hline & $\begin{array}{l}\text { Coefficient } \\
\text { Sig. (2- } \\
\text { Tailed) }\end{array}$ & .363 & .071 & . & .474 \\
\hline & $\mathrm{N}$ & 115 & 115 & 115 & 115 \\
\hline \multirow{3}{*}{$\begin{array}{l}\text { Organisatio } \\
\text { nal } \\
\text { Commitme } \\
\text { nt }\end{array}$} & $\begin{array}{l}\text { Correlation } \\
\text { Coefficient }\end{array}$ & .116 & $.372^{* *}$ & .067 & 1.000 \\
\hline & $\begin{array}{l}\text { Sig. (2- } \\
\text { Tailed) }\end{array}$ & .217 & .000 & .474 & . \\
\hline & $\mathrm{N}$ & 115 & 115 & 115 & 115 \\
\hline
\end{tabular}

Source: Field survey (2017) Scale: 2.0-2.4= Low and 2.5 and above= High

Since only training and orientation was found to have had a significant relationship with organisational commitment, the study therefore rejected the alternative hypothesis which states that there is statistically positive significant relationship between organisational commitment and variables of the study such as work 
relations, training and orientation, and extrinsic rewards.

$$
\text { Irefin and Ali's (2014) }
$$

found that antecedents such as personal characteristics, structural/organisational characteristics, job-related characteristics, and demographic characteristics such as work experiences, age, tenure, gender and education and job status influence organisational commitment. It is for this purpose that this section test hypotheses that relate to demographic characteristics and variables of the study. Demographic characteristics considered in this section were sex, tenure and employment type. Educational level was not considered because it was already used to categorized staff of the college into junior staff, senior staff and senior members.

Hypothesis Two

HO: $\quad$ There is a statistically significance difference between sex of respondents and the variables of the study such as work relations, training and orientation, extrinsic reward and organisational commitment.

The second hypothesis was tested with independent t-test and the results can be seen from Table 7. All t- values reported for the variables were in line with the equal variance assumed because all the Sig. values obtained under the Levene's test for equality of variances were above .05 threshold. This means that none of the assumptions for using t-test was breached. The results as indicated by the Sig (2 tailed) under t-test for equality of means in Table 7 means that there were no statistically significance differences in scores respectively for male and female perception of organisational commitment $[(\mathrm{M}=2.64, \mathrm{SD}=.698)$; $(\mathrm{M}=2.56, \mathrm{SD}=.586) ; \mathrm{t}(115)=.488)]$; work relations $[\mathrm{M}=2.59, \mathrm{SD}=.807)$; $(\mathrm{M}=2.67, \mathrm{SD}=.853) ; \mathrm{t}(115)=.609]$; training and orientation $[(\mathrm{M}=2.54$, $\mathrm{SD}=.543) \quad(\mathrm{M}=2.43, \mathrm{SD}=.444)$; $\mathrm{t}(115)=.252]$ and extrinsic reward [ $(\mathrm{M}=2.13, \quad \mathrm{SD}=.594) ; \quad(\mathrm{M}=2.00$ $\mathrm{SD}=.612) \mathrm{t}=(115)=.261)]$. 
Table 7: Differences in Perception of the Factors of the Study Based on Sex

\begin{tabular}{|c|c|c|c|c|c|c|c|c|c|}
\hline \multirow[t]{3}{*}{ Variables } & \multirow[b]{3}{*}{ Sex } & \multirow[b]{3}{*}{$\mathrm{N}$} & \multirow[b]{3}{*}{ Mean } & \multirow[b]{2}{*}{ Std. } & \multirow[b]{2}{*}{ Std. } & \multicolumn{2}{|c|}{$\begin{array}{l}\text { Levene's Test } \\
\text { for Equality } \\
\text { of Variances }\end{array}$} & \multicolumn{2}{|c|}{$\begin{array}{l}\text { t-test for } \\
\text { Equality of } \\
\text { Means }\end{array}$} \\
\hline & & & & & & $\mathrm{F}$ & Sig & $\mathrm{T}$ & $\begin{array}{l}\text { Sig (2- } \\
\text { tailed }\end{array}$ \\
\hline & & & & $\mathrm{v}$ & Error & & & & \\
\hline \multirow{4}{*}{$\begin{array}{l}\text { Organisationa } \\
1 \text { Commitment }\end{array}$} & Male & 70 & 2.64 & .69 & .083 & 2.416 & .123 & .696 & .488 \\
\hline & & & & 8 & & & & & \\
\hline & Femal & 45 & 2.56 & .58 & .087 & & & & \\
\hline & e & & & 6 & & & & & \\
\hline \multirow{4}{*}{$\begin{array}{l}\text { Work } \\
\text { Relations }\end{array}$} & Male & 70 & 2.59 & .80 & .097 & .097 & .757 & .513 & .609 \\
\hline & & & & 7 & & & & & \\
\hline & Femal & 45 & 2.67 & .85 & .127 & & & & \\
\hline & e & & & 3 & & & & & \\
\hline \multirow{4}{*}{$\begin{array}{l}\text { Training \& } \\
\text { orientation }\end{array}$} & Male & 70 & 2.54 & .54 & .065 & 3.257 & .074 & 1.15 & .252 \\
\hline & & & & 3 & & & & 2 & \\
\hline & Femal & 45 & 2.43 & .44 & .066 & & & & \\
\hline & $\mathrm{e}$ & & & 4 & & & & & \\
\hline \multirow{4}{*}{$\begin{array}{l}\text { Extrinsic } \\
\text { Reward }\end{array}$} & Male & 70 & 2.13 & .59 & .071 & .027 & .869 & 1.12 & .261 \\
\hline & & & & 4 & & & & 9 & \\
\hline & Femal & 45 & 2.00 & .61 & .091 & & & & \\
\hline & $\mathrm{e}$ & & & 2 & & & & & \\
\hline
\end{tabular}

Source: Field survey (2017) Scale: 2.0-2.4= Low and 2.5 and above= High

Meanwhile, (except for work relations) male staff perceived commitment, training and orientation, and extrinsic reward more positively as compared to their female counterparts. The findings of this study of non-significance of the varables of the study thus disagree with that of Irefin and Ali's (2014) that organisational characteristics and job-related characteristics influence organisational commitment. Based on the result of non-significance of the factors of study, the eta square showing the size of the effect was not calculated. The alternative hypothesis which indicates that there is a statistically significance difference in how male and female staff perceived work 
relations, training and orientation, extrinsic reward and organisational commitment was therefore rejected.

Hypothesis Three

HO: There is a statistically positive and significance difference between type of employment and variables of the study such as work relations, training and orientation, extrinsic reward and organisational commitment.
The third hypothesis of the study also examined whether there were statistical significance differences in terms of how the factors of the study were perceived by teaching staff as compared to nonteaching staff of the college (herein referred to as type of employment). The results can be found in Table 8 .

Table 8: Differences in Perception of the Factors of the Study Based on Type of Employment

\begin{tabular}{|c|c|c|c|c|c|c|c|c|}
\hline \multirow[t]{2}{*}{ Variables } & \multirow[t]{2}{*}{$\begin{array}{l}\text { Type of } \\
\text { employme } \\
\text { nt }\end{array}$} & \multicolumn{2}{|c|}{$\begin{array}{l}\text { Mea } \\
\mathrm{N} \text { n }\end{array}$} & \multirow[t]{2}{*}{$\begin{array}{l}\cdot \\
\text { Std. } \\
\text { Dev }\end{array}$} & \multirow[t]{2}{*}{$\begin{array}{r}\text { Std. } \\
\text { Error }\end{array}$} & $\begin{array}{l}\text { Levene's } \\
\text { Test for } \\
\text { Equality of } \\
\text { Variances }\end{array}$ & \multicolumn{2}{|c|}{$\begin{array}{l}\mathrm{t} \text {-test for } \\
\text { Equality of } \\
\text { Means }\end{array}$} \\
\hline & & & & & & F $\quad$ Sig & $\mathrm{t}$ & $\begin{array}{l}\text { Sig (2- } \\
\text { tailed) }\end{array}$ \\
\hline Organisational & 1 Teaching & 17 & 2.74 & .615 & .149 & $000 \quad 766$ & 867 & 200 \\
\hline & $\begin{array}{l}\text { Non - } \\
\text { teaching }\end{array}$ & 98 & 2.59 & .662 & .067 & & & \\
\hline Work & Teaching & 17 & 2.06 & .746 & .181 & & & \\
\hline Relations & $\begin{array}{l}\text { Non - } \\
\text { teaching }\end{array}$ & 98 & 2.71 & .799 & .081 & .676. 413 & 3.149 & .002 \\
\hline & Teaching & 17 & 2.28 & .439 & .106 & & & \\
\hline
\end{tabular}




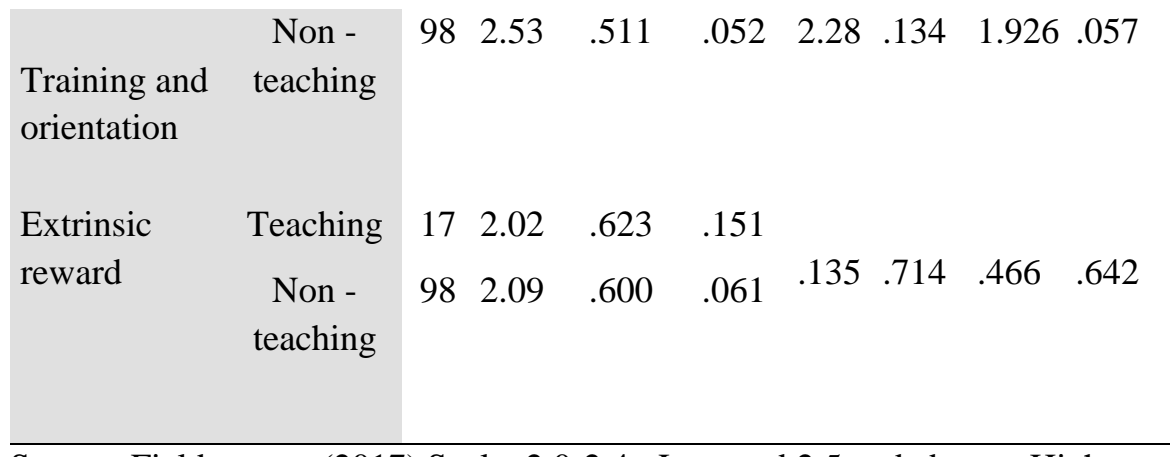

Source: Field survey (2017) Scale: 2.0-2.4= Low and 2.5 and above= High

From Table 8, it is obvious that apart from organisational commitment, non-teaching staff of the College perceived work relations, training and orientation, and extrinsic reward more positively than the teaching staff. The results as indicated by the Sig ( 2 tailed) under t-test for equality of means in Table 8 means that there were no statistical significance differences in scores respectively for teaching and non-teaching staff of the college with regards extrinsic reward $[(\mathrm{M}=2.0196, \mathrm{SD}=. .62328)$; $(\mathrm{M}=2.0935, \mathrm{SD}=.60024) ; \mathrm{t}(115)=$ $.488)]$; and organisational commitment $\quad[\mathrm{M}=2.7353$, $\mathrm{SD}=.61537) ; \quad(\mathrm{M}=2.5867$, $\mathrm{SD}=.66202) ; \mathrm{t}(115)=.390]$.

Meanwhile there was a statistically significant difference in terms of how teaching and nonteaching staff respectively perceived training and orientation $[(\mathrm{M}=2.2794, \mathrm{SD}=.43868) \quad(\mathrm{M}=$ 2.5332, $\mathrm{SD}=.51101) ; \mathrm{t}(115)=.057]$ and work relations $[\mathrm{M}=2.0588$, $\mathrm{SD}=.74755) ; \quad(\mathrm{M}=2.7143$ $\mathrm{SD}=.79948) \mathrm{t}=(115)=.002)]$. The magnitude of the differences in the means was small for training and orientation (eta squared $=0.03$ ) and great for work relations $(0.08)$. The alternative hypothesis that there is a statistically positive and significance difference between type of employment and variables of the study was therefore rejected.

Hypothesis Four

HO: There is a statistically significance difference between types of organisational commitment and tenure.

Hypothesis four was tested with the use of analysis of variance 
(ANOVA). A two-way between group analysis of variance was conducted to explore the impact of working experience herein termed as tenure on the various types of commitment and the three independent variables of the study, as measured by the life orientation test (LOT). Subjects were divided into three main groups according to their number of years of working in the college (Group 1: 1-5 years; Group 2: 6- 9 years; Group 3: 10 years and above) and the results can be found in Table 9. From the table, staff with six to nine (6-9) years working experience perceived affective commitment $(\mathrm{M}=2.96, \mathrm{SD}=.594)$ and normative commitment ( $\mathrm{M}=2.69$, $\mathrm{SD}=.855)$; extrinsic reward $(\mathrm{M}=$ $2.15, \mathrm{SD}=.551)$ and work relations $(\mathrm{M}=3.00, \mathrm{SD}=.817)$ higher than all other age categories of staff.

Staff with 10 years and above working experience also perceived continuance commitment
$(\mathrm{M}=3.00, \mathrm{SD}=1.00)$ and training and orientation $\quad(\mathrm{M}=2.700, \quad \mathrm{SD}=.168)$ higher that the other two age categories. Meanwhile, there was no statistically significance differences between age and affective commitment $\left[\begin{array}{lll}\mathrm{F} & (2.536) & =.084)\end{array}\right]$, continuance commitment [F (1.181) $=.311)]$, normative commitment $[\mathrm{F}$ $(=0.670)=.514)$ ], extrinsic rewards [ $\mathrm{F}(1.119)=.330)]$, work relations [ $\mathrm{F}$ $(1.606)=.205)]$ and training and orientation $[\mathrm{F}(1.054)=.352)]$. Irefin and Ali's (2014) findings that demographic characteristics like age influences commitment was therefore not corroborated by this study. Based on the non-significance of commitment and all the other variables of the study, the alternative hypothesis which states that there is a statistically significance difference between types of organisational commitment and tenure was therefore rejected. 
Table 9: Differences in Organisational Commitment Based on Age of Respondents

\begin{tabular}{|c|c|c|c|c|c|c|c|}
\hline Variables & Age & $\mathrm{N}$ & Mean & $\begin{array}{l}\text { Std. } \\
\text { Dev. }\end{array}$ & $\begin{array}{r}\text { Std. } \\
\text { Error }\end{array}$ & $\mathrm{F}$ & Sig. \\
\hline \multirow{4}{*}{$\begin{array}{l}\text { affective } \\
\text { commitment }\end{array}$} & $1-5$ years & 97 & 2.55 & .663 & .067 & \multirow[t]{4}{*}{2.536} & \multirow[t]{4}{*}{.084} \\
\hline & $6-9$ & 13 & 2.96 & .594 & .165 & & \\
\hline & $\begin{array}{l}10 \text { years \& } \\
\text { above }\end{array}$ & 5 & 2.80 & .274 & .123 & & \\
\hline & Total & 115 & 2.61 & .655 & .061 & & \\
\hline \multirow{4}{*}{$\begin{array}{l}\text { Continuance } \\
\text { Commitment }\end{array}$} & $1-5$ years & 97 & 2.39 & .873 & .089 & \multirow[t]{4}{*}{1.181} & \multirow[t]{4}{*}{.311} \\
\hline & $6-9$ & 13 & 2.39 & .768 & .213 & & \\
\hline & $\begin{array}{l}10 \text { years \& } \\
\text { above }\end{array}$ & 5 & 3.00 & 1.00 & .447 & & \\
\hline & Total & 115 & 2.42 & .868 & .082 & & \\
\hline \multirow{4}{*}{$\begin{array}{l}\text { Normative } \\
\text { Commitment }\end{array}$} & $1-5$ years & 97 & 2.40 & .862 & .088 & \multirow[t]{4}{*}{.670} & \multirow[t]{4}{*}{.514} \\
\hline & $6-9$ & 13 & 2.69 & .855 & .237 & & \\
\hline & $\begin{array}{l}10 \text { years \& } \\
\text { above }\end{array}$ & 5 & 2.40 & .548 & .245 & & \\
\hline & Total & 115 & 2.44 & .849 & .079 & & \\
\hline \multirow{4}{*}{$\begin{array}{l}\text { Extrinsic } \\
\text { Reward }\end{array}$} & $1-5$ years & 97 & 2.09 & .608 & .062 & \multirow[t]{4}{*}{1.119} & \multirow[t]{4}{*}{.330} \\
\hline & $6-9$ & 13 & 2.15 & .551 & .153 & & \\
\hline & $10 \&$ above & 5 & 1.70 & .570 & .255 & & \\
\hline & Total & 115 & 2.08 & .602 & .056 & & \\
\hline \multirow[t]{4}{*}{ work relations } & $1-5$ years & 97 & 2.57 & .828 & .084 & \multirow[t]{4}{*}{1.606} & \multirow[t]{4}{*}{.205} \\
\hline & 6-9 years & 13 & 3.00 & .817 & .227 & & \\
\hline & $\begin{array}{l}10 \text { years } \& \\
\text { above }\end{array}$ & 5 & 2.60 & .548 & .245 & & \\
\hline & Total & 115 & 2.62 & .823 & .078 & & \\
\hline \multirow{2}{*}{$\begin{array}{l}\text { Training \& } \\
\text { Orientation }\end{array}$} & $1-5$ years & 97 & 2.47 & .516 & .052 & \multirow[t]{2}{*}{1.054} & \multirow[t]{2}{*}{.352} \\
\hline & $6-9$ & 13 & 2.63 & .509 & .141 & & \\
\hline
\end{tabular}




$\begin{array}{lrrrr}\begin{array}{l}10 \text { years \& } \\ \text { above }\end{array} & 5 & 2.70 & .168 & .075 \\ \text { Total } & 115 & 2.49 & .507 & .047\end{array}$

Source: Field survey (2017) Scale: 2.0-2.4= Low and 2.5 and above= High

\section{Conclusion}

The purpose of the study was to examine human resource factors and organisational commitment at College of Distance Education, University of Cape Coast, Ghana. The human resource factors examined were extrinsic rewards, training and orientation, and work relations. The study found that commitment level among staff at the college (CoDE) was found to be high. Affective commitment was perceived higher than normative and continuance dimensions of organisational commitment. Senior members of the college perceived affective commitment higher whiles junior staff perceived continuance commitment higher.

Work relations were perceived to be higher compared to training and orientation and extrinsic reward. The study also found that only training and orientation had a statistically significant relationship with organisational commitment. There was no statistically significance effect of age and sex of respondents on organisational commitment, extrinsic rewards, training and orientation, and work relations. Apart from work relations, all other factors of the study were perceived higher by non-teaching staff as compared to the teaching staff of the college. Type of employment (teaching and nonteaching) was found to have had a statistically significance effect on work relations at the College of Distance Education.

The above findings indicate a need for certain action to take place by management (advisory committee). It is, therefore, recommended that the management of CoDE should:

1. Pay more attention to work relations at the college by engaging staff of the college in inter-unit or interdepartmental assignments to enable staff to build more work relations.

2. Organize college level socialization activities like sporting activities, health walk among others on 
public holidays for the staff

of the college to fraternize in order to enhance work relations.

3. Continue with training and orientation for staff of the college by introducing both on- the- job and off- the- job methods in order to maintain or enhance the commitment level of staff of the college. 


\section{References}

Amedahe, F. K., \& Gyimah, E. A. (2015). Introduction to education research. Cape Coast: College of Distance Education. Cape Coast, Ghana: University of Cape Coast Press

Armstrong, M. \& Murlis, H. (2007). Reward management: A handbook of remuneration strategy and practice (5th ed.). London: Kogan Page Ltd.

Becker, H. S. (1960). Notes on the concepts of commitment. American Journal of Sociology, 66, 32 - 40.

Brunetto, Y., Xerri,M, Shriberg, A., Rod, F., Newman, K., \& Dienger, S. (2013). The impact of workplace relationships on engagement, well-being, commitment and turnover for nurses in Australia and the USA. Queensland, Australia: University of Griffith Press.

Betz, M.K. (2005). Distance Education: A Systems View. Journal of Information and Communication Technology Education, 1(4), 70-82.
Coetzee, M., Schreuder, D., \& Tladinyane, R. (2014). Employees' work engagement and job commitment: The moderating role of career anchors. SA Journal of Human Resource Management, 12(1) 1-12.

Coffie1, B. R., Boateng, K. A. \& Coffie, F. (2018). Achieving organisational commitment through HRM practices: The Ghanaian banking sector experience. International Journal of Business and Management; 13, (5); 171184.

Delery, J. E. and Doty, D. H. (1996). Modes of theorizing in strategic human resource management: Tests of universalistic, contingency and configurational performance predictions. Academy of Management Journal, 39 (4), 802-835

Funminiyi, K.A. (2018). Impact of workplace environmental factors on employee commitment: Evidence from North East Nigeria. International Journal of Scientific Research and 
Management, 06 (07), 575585.

Gellatly, I. R., Hunter, K. H., Currie,

L. G., \& Irving, G. (2009). HRM practices and organisational commitment. The International Journal of Human Resource Management, 20 (4), 869884.

Irefin, P. \& Ali, M.M. (2014). Effect of employee commitment on organisational performance in Coca Cola Nigeria Limited Maiduguri, Borno State, Nigeria. Journal of Humanities and Social Science, 19 (3), 33-42.

Jackson, J. H., \& Mathis, R. L. (2006). Human resource management. $\left(11^{\text {th }} \quad\right.$ ed.). New York: West Publishing Co.

Jafari, S., Afshin, T., Jafari, K., \& Barzegar, M. (2015). Evaluation of organisational commitment among nurses in Intensive Care Units. Journal of Nursing and Midwifery Sciences, 2 (3), 38-43.

Jørgensen, F. \& Becker, K. (2015),

Balancing organisational and professional commitments in professional service firms:

The HR practices that matter. The International Journal of Human Resource Management, 26 (1); 23-41.

Kessler, E.H. (2013). Encyclopedia of management theory. Los Angeles, Sage publication.

Krejcie \& Mor-gan (1970). Determining sample size for research activities. Educational and Psychological Measurement; 30 (2), 607610.

Mahesar, H. A. (2015). The impact of HRM bundles and organisational commitment on managers turnover intentions. London, UK: University of Bedfordshire Press.

Meyer, J. P. \& Allen, N. J. (1984). Commitment in the workplace: Theory, research, and application. Thousand Oaks, CA: Sage.

Moore, M. G. \&Kearsley, G. (2005). Distance education: A systems view $\left(2^{\text {nd }} \mathrm{ed}.\right)$. Belmont: Wadsworth Publishing Company. 
Paşaoğlu, D. (2015). Analysis of the relationship between human resources management practices and organisational commitment from a strategic perspective: Findings from the banking industry. Procedia-Social and Behavioral Sciences, 207 (22), 315-324.

Porter, L. W, Steers, R., Mowday, R. T. \& Boulian,V. P. (1974). Organisational commitment, job satisfaction, and turnover among psychiatric technicians. Journal of Applied Psychology, 59 (5), 603-623.

Price, J. L. \& Mueller, C. W. (1986). Handbook of organisational measurement. Cambridge, MA: Ballinger.

Sawithri, L.D., Nishanthi, H. M. \& Amarasinghe, K. G. (2017). The impact of employeremployee relations on employee commitment: A case from Sri Lanka. Kelaniya Journal of Human Resource Management, 12 (2), 174-192.

Segbenya, Peniana \& Aggrey (2018). Effect of work conflict on employees' job satisfaction: The case of College of Distance Education, University of Cape Coast. European Scientific Journal, 14 (7), 313-323

Shaw, J. D. (2014). Pay levels and pay changes. Strategic Management Journal, 22 (2); 379-386.

Sthapit, A. (2014). What drives employees to switch organisations? A study of factors affecting inter-bank HR-turnover. Journal of Business Studies, 13 (1), 7388.

Wan, H. L. (2007). Human capital development policies: Enhancing employees' satisfaction. Journal of European Industrial Training, 31(4), 297-319. 